\title{
Isolation and Identification of Poly(3-Hydroxyvalerate)-Degrading Strains of Pseudomonas lemoignei
}

\author{
JORIS MERGAERT, ${ }^{1 *}$ ANDREAS SCHIRMER,${ }^{2}$ LYSIANE HAUBEN,${ }^{1,3}$ MARGIT MAU, ${ }^{3}$ BART HOSTE ${ }^{1}$ \\ K. KERSTERS, ${ }^{1}$ DIETER JENDROSSEK, ${ }^{2}$ AND JEAN SWINGS ${ }^{1}$
Laboratorium voor Microbiologie, Vakgroep Biochemie, Fysiologie en Microbiologie, Universiteit Gent, B-9000 Ghent, Belgium, ${ }^{1}$ and Institut für Mikrobiologie der Georg-August-Universität zu Göttingen, D-37077 Göttingen, ${ }^{2}$ and Gesellschaft für Biotechnologische Forschung, Abteilung Mikrobiologie, D-38124 Braunschweig, ${ }^{3}$ Germany

\begin{abstract}
By using selective enrichment of polyhydroxyalkanoate-degrading bacteria and poly(3-hydroxyvalerate)containing granules from Chromobacterium violaceum as the carbon source, 10 new Pseudomonas lemoignei strains were isolated; these strains were able to degrade poly(3-hydroxyvalerate), as well as poly(3-hydroxybutyrate), in vitro. The new isolates were characterized and identified by comparing them with $P$. lemoignei LMG $2207^{\mathrm{T}}\left(\mathrm{T}=\right.$ type strain). Like $P$. lemoignei LMG $2207^{\mathrm{T}}$ cells, the cells of the $10 \mathrm{new}$ isolates contained mainly hexadecenoic, hexadecanoic, octadecenoic, and dodecanoic acids, as well as hydroxylated fatty acids, and exhibited respiration in the presence of methylpyruvate, 3-hydroxybutyrate, and 4-hydroxybutyrate, but not in the presence of the 92 other carbon sources included in Biolog GN microplates. The protein patterns of the new isolates were almost identical to each other and very similar to the protein pattern of $P$. lemoignei LMG $2207^{\mathrm{T}}$. Some of the new isolates, but not $P$. lemoignei LMG $2207^{\mathrm{T}}$, contained megaplasmids that were about 200 kbp long. The 16S ribosomal DNA genes of strain A62, a representative of the 10 new isolates, and of $P$. lemoignei LMG $2207^{\mathrm{T}}$ exhibited more than 0.99 sequence similarity. The DNA-DNA reassociation value for two representative strains was $\mathbf{1 0 0 \%}$, and the levels of DNA-DNA reassociation between these strains and the type strain were 60 and $61 \%$. The taxonomy of $P$. lemoignei is briefly discussed.
\end{abstract}

Polyhydroxyalkanoates (PHAs) are biodegradable polyesters that are synthesized and accumulated intracellularly under limiting growth conditions by a large variety of bacteria. $\mathrm{Be}$ sides poly(3-hydroxybutyrate) $[\mathrm{P}(3 \mathrm{HB})]$, polymers incorporating monomers other than 3-hydroxybutyrate have been detected. The monomer composition of the PHAs depends on the bacterial strain, as well as on the carbon sources supplied. The production of PHAs has been reviewed previously $(2,11$, $39,41)$. Because of their biodegradability, thermoplastic properties, and synthesis from renewable resources, PHAs are of biotechnological interest, and $\mathrm{P}(3 \mathrm{HB})$ and copolymers of 3-hydroxybutyrate and 3-hydroxyvalerate (3) have been commercialized as Biopol, an alternative to petrochemically derived, nondegradable plastics. The biodegradability of Biopol has been demonstrated in different natural environments, and a large variety of PHA-degrading microorganisms, including gram-negative and gram-positive bacteria, streptomycetes, and molds, have been isolated $(5,14,24,25,27-29,33,34)$. One of the first $\mathrm{P}(3 \mathrm{HB})$-degrading microorganisms identified was isolated more than 30 years ago and was named Pseudomonas lemoignei (7). Three P. lemoignei strains were the predominant microorganisms after enrichment in liquid medium containing $\mathrm{P}(3 \mathrm{HB})$ granules. Only the type strain of this taxon has been preserved, and no PHA-degrading $P$. lemoignei strains have been isolated since the first isolation. The type strain of the species is particularly interesting, since it produces at least five different extracellular depolymerases (13), one of which is specifically synthesized during growth on poly(3-hydroxyvalerate) $[\mathrm{P}(3 \mathrm{HV})]$ or valerate $(30)$. Other PHA-degrading bacteria apparently synthesize only one depolymerase (13). The type

* Corresponding author. Mailing address: Laboratorium voor Microbiologie, Vakgroep Biochemie, Fysiologie en Microbiologie, Universiteit Gent, K. L. Ledeganckstraat 35, B-9000 Ghent, Belgium. Phone: 329264 5120. Fax: 329264 5346. Electronic mail address: Joris.Mergaert@rug.ac.be. strain of $P$. lemoignei is specialized and utilizes homo- and copolymers of 3-hydroxybutyrate and 3-hydroxyvalerate, their hydrolysis products, and a few organic acids (pyruvate, acetate, butyrate, valerate, succinate), but it is not able to grow on sugars, amino acids, or complex media (7).

In this paper a procedure for selective enrichment and isolation of PHA-degrading $P$. lemoignei strains, in which $\mathrm{P}(3 \mathrm{HV})$ granules are used as the carbon source, is described. Ten new $P$. lemoigne $i$ isolates were identified and characterized by using fatty acid analysis, sodium dodecyl sulfate (SDS)-polyacrylamide gel electrophoresis (PAGE) of whole-cell proteins, the Biolog breathprinting system, $16 \mathrm{~S}$ ribosomal DNA (rDNA) gene sequence analysis, DNA base composition analysis, DNA-DNA hybridization analysis, plasmid analysis, and conventional phenotypic characterization techniques.

\section{MATERIALS AND METHODS}

Isolation of $\mathbf{P}(\mathbf{3 H V})$-degrading microorganisms. To enrich for $\mathbf{P}(3 \mathrm{HV})$-degrading microorganisms, soil or compost that was collected in or near Göttingen, Germany, was placed in boxes and supplemented with PHAs. Poly(3-hydroxybutyrate-co-3-hydroxyvalerate) was added as buried Biopol bottles (Wella AG, Darmstadt, Germany), while $\mathrm{P}(3 \mathrm{HV})$ was repeatedly added as broken cells of Chromobacterium violaceum DSM 30191 which had been cultivated under conditions that promoted polymer accumulation (40). The boxes were incubated at room temperature $\left(18\right.$ to $25^{\circ} \mathrm{C}$ ) or $30^{\circ} \mathrm{C}$ for several weeks. Diluted soil or compost suspensions in $0.9 \%(\mathrm{wt} / \mathrm{vol}) \mathrm{NaCl}$ were used as inocula for $10-\mathrm{ml}$ liquid cultures of mineral medium (35) supplemented with $0.15 \%$ (wt/vol) $\mathrm{P}(3 \mathrm{HV}$ ) as the sole source of carbon and energy (14). After several days of aerobic incubation, clearing of the opaque $\mathrm{P}(3 \mathrm{HV})$ suspensions was observed in most of the cultures. After a second incubation step performed with fresh medium under the same conditions, dilutions were streaked onto solid mineral medium supplemented with $0.3 \%$ (wt/vol) $\mathrm{P}(3 \mathrm{HV})$ as the sole carbon source. $\mathrm{P}(3 \mathrm{HV})$-degrading bacteria were recognized by the appearance of clear halos surrounding the colonies (14) and were purified by alternate plating on mineral medium containing either $\mathrm{P}(3 \mathrm{HV})$ or sodium valerate $(0.15 \%$, wt/vol). The 10 strains obtained were deposited in the Laboratorium voor Microbiologie Gent Culture Collection (LMG), Ghent, Belgium, as P. lemoignei strains. $P$. lemoignei $\mathrm{LMG} 2207^{\mathrm{T}}$ ( T = type strain) was obtained from LMG.

PHA accumulation. PHA accumulation was determined by performing a gas chromatographic analysis of the corresponding 3-hydroxymethyl esters of lyophilized cells (4). 
Fatty acid analysis. Strains were grown on Trypticase soy broth (BBL) supplemented with $1.5 \%$ (wt/vol) Bacto Agar (Difco) and $0.1 \%$ (wt/vol) sodium-DL3-hydroxybutyrate (Serva) for 3 days at $28^{\circ} \mathrm{C}$. Fatty acid methyl esters were prepared and separated by gas-liquid chromatography as described previously (1), with some modifications (26). The Microbial Identification System (Microbial ID, Inc., Newark, Del.) software package was used to identify the fatty acids. The same software package was used to cluster the fatty acid methyl ester profiles by the unweighted pair group method of averages (37) of Euclidean distances, which were calculated for each pair of profiles.

Breathprinting with the Biolog system. Strains were grown on Delafield medium (7) supplemented with $0.3 \%$ (wt/vol) 3-hydroxybutyrate for 2 days at $28^{\circ} \mathrm{C}$ Suspensions were prepared, and Biolog GN microplates (Biolog, Inc., Hayward, Calif.) were inoculated as recommended by the manufacturer. After 3 days of incubation at $28^{\circ} \mathrm{C}$, the plates were read visually, and wells showing any color reaction, compared with the control well were interpreted as positive.

Plasmid analysis. A plasmid analysis was performed by the method of Kado and Liu (16). Plasmid preparations were loaded onto an $0.8 \%$ (wt/vol) agarose gel and stained with ethidium bromide after electrophoresis.

SDS-PAGE of whole-cell proteins. The bacterial cells in 2-ml stationary cultures grown with sodium valerate were harvested by centrifugation, resuspended in $0.2 \mathrm{ml}$ of denaturation buffer, and boiled for $5 \mathrm{~min}$. For SDS-PAGE, the method of Laemmli (19) was used. A $15-\mu$ l portion of each extract was loaded onto an SDS $-12 \%$ (wt/vol) polyacrylamide gel. After electrophoresis, the proteins were stained with Coomassie blue and compared visually.

16S rDNA gene sequencing. The strains were incubated for 7 days in $5-\mathrm{ml}$ portions of Trypticase soy broth (1.7\% [wt/vol] Bacto Tryptone [Difco], 0.3\%, [wt/vol] Bacto Soytone [Difco], 0.25\% [wt/vol] Bacto Dextrose [Difco], 0.5\% [wt $/ \mathrm{vol}] \mathrm{NaCl}, 0.25 \%$ [wt/vol] $\mathrm{K}_{2} \mathrm{HPO}_{4}$ ) supplemented with $0.1 \%$ (wt/vol) DL-3hydroxybutyrate under aerobic conditions. The genomic DNA of each strain was extracted by the method of Wilson (43). The $16 \mathrm{~S}$ rDNA was amplified by PCR as described by Karlson et al. (17). The PCR products were sequenced directly by using a Taq Dye Deoxy terminator cycle sequencing kit (Applied Biosystems, Inc., Foster City, Calif.), and electrophoresis was performed with a model $373 \mathrm{~A}$ automatic sequencer (Applied Biosystems). The 16S rDNA sequences were aligned by using the sequence editing and analyzing program of Olsen (31) and reference sequences from members of the Proteobacteria obtained from the Ribosomal RNA Database Project (20). Conserved regions were used for the initial alignment. Alignment of variable regions was aided by the results of an analysis of the secondary structure. Overall similarity values, incorporating the Jukes and Cantor (15) correction factor, were calculated for sequence pair comparisons.

DNA base composition and DNA-DNA hybridizations. To prepare DNA, cells were grown at $28^{\circ} \mathrm{C}$ for 4 days in Roux flasks on minimal medium (7) supplemented with $0.3 \%$ (wt/vol) DL-3-hydroxybutyrate. DNA was prepared by the method of Marmur (22). The mean guanine-plus-cytosine $(\mathrm{G}+\mathrm{C})$ contents of DNAs were determined by the thermal denaturation method $(8,23)$. Levels of DNA-DNA binding, expressed as percentages, were determined spectrophotometrically by the initial renaturation rate method of De Ley et al. (9). Each value was the average of the values from two hybridization experiments. The total DNA concentration used was $59 \mu \mathrm{g} / \mathrm{ml}$, and the optimal renaturation temperature, calculated from the $\mathrm{G}+\mathrm{C}$ content with the equation of De Ley (8), was $77.3^{\circ} \mathrm{C}$ in $2 \times$ standard saline citrate buffer (SSC) (1× SSC is $0.15 \mathrm{M} \mathrm{NaCl}$ plus $0.015 \mathrm{M}$ sodium citrate, $\mathrm{pH} 7$ ).

Electron microscopy. Cells grown on minimal medium (35) supplemented with $0.3 \%$ (wt/vol) DL-3-hydroxybutyrate were negatively stained with $3 \%$ phosphotungstate and examined with a Phillips model EM 301 electron microscope operated at $80 \mathrm{kV}$.

Nucleotide sequence accession numbers. The 16S rDNA gene sequences of $P$. lemoignei $\mathrm{LMG} 2207^{\mathrm{T}}$ and strain A62 have been deposited in the EMBL data library under accession numbers X92555 and X92554, respectively.

\section{RESULTS}

Isolation of $\mathbf{P}(\mathbf{3 H V})$-degrading bacteria. After the enrichment procedure, 10 bacterial strains that are able to use $\mathrm{P}(3 \mathrm{HV})$ as a sole source of carbon and energy were isolated on P(3HV)-containing media. Strains A51 (= LMG 16484), A52 (= LMG 16485), A53 (= LMG 16486), A58 (= LMG 16487), A60a (= LMG 16488), and A60b (= LMG 16489) were isolated from a box containing garden soil supplemented with broken Biopol bottles and incubated at $30^{\circ} \mathrm{C}$. Strains A62 (= LMG 16480) and A64 (= LMG 16841) were isolated from a box containing soil from a meadow, and strains K21 (= LMG 16842) and $\mathrm{K} 24$ (= LMG 16843) were isolated from a box containing compost. Both of the latter boxes were supplemented with $\mathrm{P}(3 \mathrm{HV})$-containing $C$. violaceum cells and were incubated at room temperature. Like P. lemoignei $\mathrm{LMG} 2207^{\mathrm{T}}$, these gram-negative, oxidase- and catalase-positive isolates

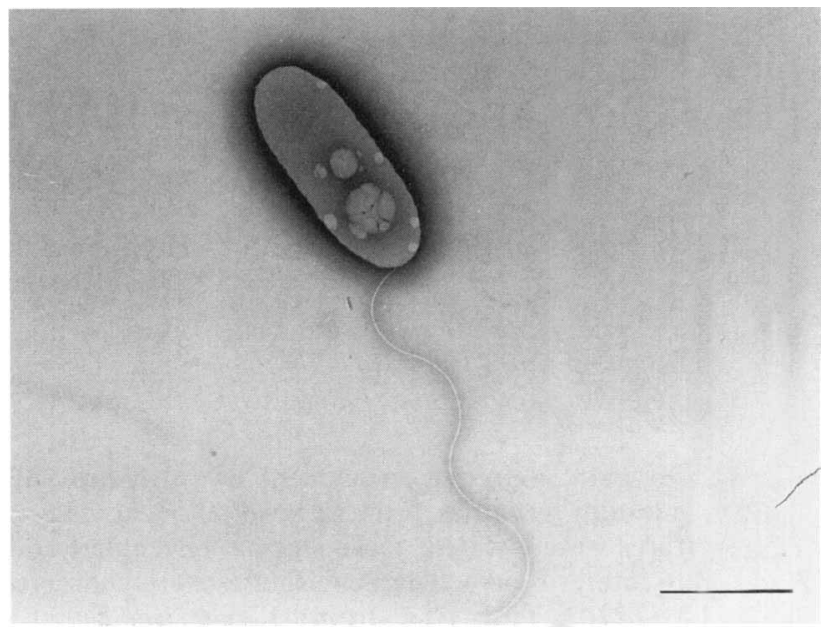

FIG. 1. Electron micrograph of a negatively stained cell of strain A62. Bar = $1 \mu \mathrm{m}$. (Prepared by M. Hoppert.)

grew slowly on solid mineral medium supplemented with valerate or 3-hydroxybutyrate, forming small, circular, cream-colored colonies which strongly adhered to the agar, and growth on butyrate $(0.3 \%, \mathrm{wt} / \mathrm{vol})$ was very poor. None of the new isolates or $P$. lemoignei $\mathrm{LMG} 2207^{\mathrm{T}}$ grew on rich media like nutrient broth (Oxoid) or Luria-Bertani medium (1\% [wt/vol] tryptone [Oxoid], $0.5 \%$ [wt/vol] yeast extract [Oxoid], $1 \%$ [wt/ vol] $\mathrm{NaCl} ; \mathrm{pH} 7.5)$ or with sugars, such as glucose $(0.5 \%$, $\mathrm{wt} / \mathrm{vol})$ and fructose $(0.5 \%, \mathrm{wt} / \mathrm{vol})$, as sole carbon sources. However, all of the strains were capable of extracellular degradation of $\mathrm{P}(3 \mathrm{HB})$ and $\mathrm{P}(3 \mathrm{HV})$ and intracellular synthesis of $\mathrm{P}(3 \mathrm{HB})$ and poly(3-hydroxybutyrate-co-3-hydroxyvalerate). In the presence of tyrosine $(0.05 \%, \mathrm{wt} / \mathrm{vol})$, a brown pigment was

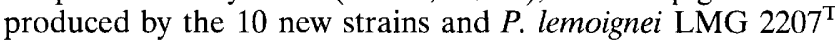
on media supplemented with $\mathrm{P}(3 \mathrm{HB})$ but not on media supplemented with DL-3-hydroxybutyrate. Cells of all of these strains were motile, displaying alternating backward movement and forward movement. Electron micrographs of cells of strains A62 (Fig. 1), K24, and A51, as well as P. lemoignei LMG $2207^{\mathrm{T}}$ (data not shown), revealed the presence of a single monopolar inserted flagellum and electron transparent inclusions that might be $\mathrm{P}(3 \mathrm{HB})$ granules. When enrichment for $\mathrm{P}(3 \mathrm{HV})$-degrading microorganisms was omitted and dilutions of soil samples were directly plated onto $\mathrm{P}(3 \mathrm{HV})$ agar plates, three $\mathrm{P}(3 \mathrm{HV})$-degrading actinomycetes and two gram-negative strains, which clearly differed from $P$. lemoignei LMG $2207^{\mathrm{T}}$, were isolated.

Characterization of the isolates by fatty acid analysis. The 10 new isolates were compared with $P$. lemoignei LMG $2207^{\mathrm{T}}$ by performing a fatty acid analysis. The fatty acid methyl ester compositions of the strains are shown in Table 1. The dendrogram obtained by clustering the profiles is shown in Fig. 2. The fatty acid methyl ester profiles of the 10 new isolates were very similar to each other and resembled the profile of $P$. lemoignei LMG $2207^{\mathrm{T}}$. All of these organisms contain mainly hexadecenoic acid (16:1 $\omega 7 \mathrm{cis})$, hexadecanoic acid (16:0), octadecenoic acid (summed feature 7), and dodecanoic acid (12:0), as well as hydroxylated fatty acids (Table 1 ). The 10 new isolates clustered together at a Euclidean distance of 8 and grouped with the type strain at a Euclidean distance of 16.P. lemoignei LMG $2207^{\mathrm{T}}$ differed slightly because of its higher content of octadecenoic acid (summed feature 7).

Breathprinting with the Biolog system. The metabolic breathprints of the 10 new isolates and $P$. lemoignei LMG 
TABLE 1. Fatty acid methyl ester compositions of $\mathrm{P}(3 \mathrm{HV})-$ degrading strains A51, A52, A53, A58, A60a, A60b, A62, A64, K21, and $\mathrm{K} 24$ and P. lemoignei LMG $2207^{\mathrm{T}}$

\begin{tabular}{|c|c|c|c|c|}
\hline \multirow{3}{*}{$\begin{array}{l}\text { Fatty acid } \\
\text { methyl ester }\end{array}$} & \multicolumn{3}{|c|}{ New isolates ${ }^{a}$} & \multirow{3}{*}{$\begin{array}{l}\% \text { of total fatty acids } \\
\text { in } P \text {. lemoignei } \\
\text { LMG } 2207^{\mathrm{T}}\end{array}$} \\
\hline & \multirow{2}{*}{$\begin{array}{l}\text { No. of } \\
\text { strains }^{b}\end{array}$} & \multicolumn{2}{|c|}{$\begin{array}{l}\% \text { of total } \\
\text { fatty acids }\end{array}$} & \\
\hline & & Mean & SD & \\
\hline 10:0 & 10 & 1.0 & 0.1 & $\mathrm{ND}^{c}$ \\
\hline $12: 0$ & 10 & 7.1 & 0.3 & 5.3 \\
\hline $14: 0$ & 10 & 2.6 & 0.1 & 1.3 \\
\hline $16: 0$ & 10 & 17.2 & 0.9 & 12.8 \\
\hline 18:0 & 3 & 0.3 & 0.5 & ND \\
\hline $14: 1 \omega 5^{d}$ & 5 & 0.4 & 0.5 & ND \\
\hline $16: 1 \omega 7$ cis & 10 & 37.5 & 2.9 & 39.3 \\
\hline $18: 1 \omega 9 \mathrm{cis}$ & 2 & 0.2 & 0.4 & ND \\
\hline $17: 0$ cyclo $^{d}$ & 9 & 1.9 & 1.6 & 1.9 \\
\hline $10: 03 \mathrm{OH}$ & 10 & 6.1 & 0.7 & 3.6 \\
\hline $12: 03 \mathrm{OH}$ & 10 & 8.2 & 0.3 & 5.7 \\
\hline $14: 02 \mathrm{OH}$ & 10 & 6.3 & 0.6 & 4.7 \\
\hline Summed feature $7^{e}$ & 10 & 11.2 & 0.8 & 25.5 \\
\hline
\end{tabular}

${ }^{a}$ Strains A51, A52, A53, A58, A60a, A60b, A62, A64, K21, and K24.

${ }^{b}$ Number of strains that contain each fatty acid methyl ester.

${ }^{c}$ ND, not detected.

${ }^{d}$ The position of the double bond or cyclopropane ring is not known.

${ }^{e}$ Fatty acids 18:1 $\omega 7 \mathrm{cis}, 18: 1 \omega 9$ trans, and 18:1 $\omega 12$ trans cannot be separated gas chromatographically by the Microbial Identification System and together are designated summed feature 7 .

$2207^{\mathrm{T}}$ were investigated by using Biolog GN microplates. All of the strains exhibited weak positive reactions in the wells containing methylpyruvate, 3-hydroxybutyrate, and 4-hydroxybutyrate. None of the strains produced color reactions in the presence of 28 carbohydrates, 22 other carboxylic acids, 20 amino acids, the polymers glycogen, $\alpha$-cyclodextrin, dextrin, Tween 40, and Tween 80, the alcohols 2,3-butanediol and glycerol, the amides succinamic acid, glucuronamide, and alaninamide, the amines phenylethylamine, 2-aminoethanol, and putrescine, the aromatic chemicals inosine, urocanic acid, thymidine, and uridine, the phosphorylated chemicals DL- $\alpha$-glycerol phosphate, glucose 1-phosphate, and glucose 6-phosphate, bromosuccinic acid, and monomethylsuccinate.

SDS-PAGE of whole-cell proteins. The protein patterns of the 10 new isolates were almost identical to each other and very similar to the protein pattern of $P$. lemoignei $\mathrm{LMG} 2207^{\mathrm{T}}$ (Fig. 3).
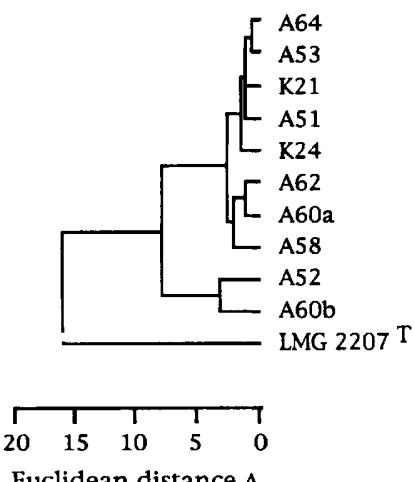

Euclidean distance $\Delta$

FIG. 2. Dendrogram grouping strains A51, A52, A53, A58, A60a, A60b, A62, A64, K21, and $\mathrm{K} 24$ and $P$. lemoignei LMG $2207^{\mathrm{T}}$ on the basis of their fatty acid methyl ester compositions.

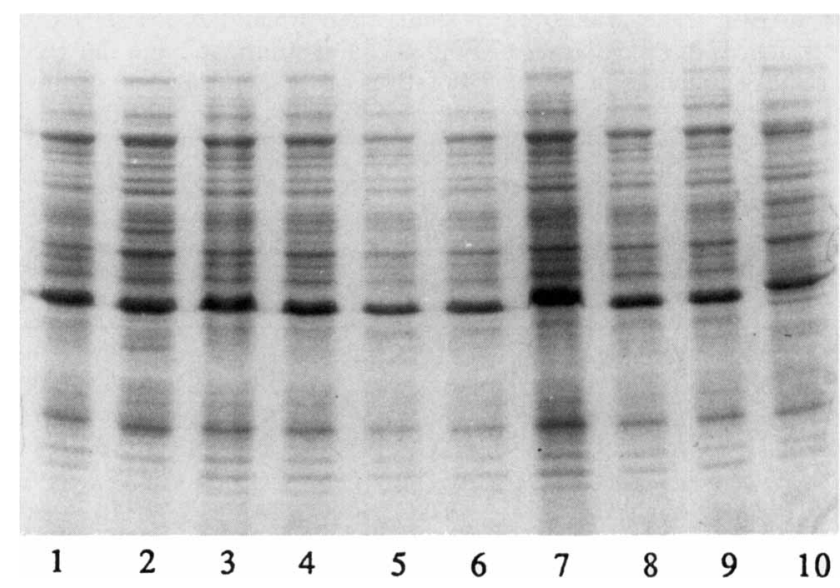

FIG. 3. SDS-PAGE of whole-cell proteins of $P$. lemoignei strains. Lane 1 , strain A51; lane 2, strain A52; lane 3, strain A53; lane 4, strain A58; lane 5, strain A60a; lane 6, strain K21; lane 7, strain K24; lane 8, strain A62; lane 9, strain A64; lane $10, P$. lemoignei $\mathrm{LMG} 2207^{\mathrm{T}}$.

Plasmid analysis. The new isolates and $P$. lemoignei LMG $2207^{\mathrm{T}}$ were analyzed to determine the presence of circular plasmids. No plasmids were detected in strains A64, K21, and K24 and $P$. lemoignei LMG $2207^{\mathrm{T}}$. Strains A51, A52, A53, A58, $\mathrm{A} 60 \mathrm{a}, \mathrm{A} 60 \mathrm{~b}$, and A62 harbored a plasmid that was about 200 $\mathrm{kbp}$ long, and strains A51 and A58 contained an additional plasmid that was about $30 \mathrm{kbp}$ long.

16S rDNA sequencing. The $16 \mathrm{~S}$ rDNA genes from strain A62, a representative of the new $P$. lemoignei isolates, and from $P$. lemoignei $\mathrm{LMG} 2207^{\mathrm{T}}$ were sequenced. The $16 \mathrm{~S}$ rDNAs of strain A62 and $P$. lemoignei LMG $2207^{\mathrm{T}}$ have a level of mutual sequence similarity and an overall level of similarity of 0.99 . The sequences differ mainly between positions 73 and 97 (Escherichia coli numbering [6]). The overall levels of similarity of the 16S rDNA sequences of these strains and 19 other representatives of the Proteobacteria are shown in Table 2. The 16S rDNA sequence analysis of $P$. lemoignei LMG $2207^{\mathrm{T}}$ and strain A62 revealed that these organisms belong to the beta subclass of the Proteobacteria. P. lemoignei LMG $2207^{\mathrm{T}}$ and strain A62 exhibited 0.94 overall similarity with Zoogloea ramigera ATCC 25935, 0.92 similarity with Burkholderia solanacearum, and 0.91 similarity with Alcaligenes eutrophus and Pseudomonas andropogonis and levels of similarity lower than 0.91 with the other representatives of the Proteobacteria, including $Z$. ramigera ATCC $19544^{\mathrm{T}}$ (Table 2).

DNA base composition and DNA-DNA hybridization. The DNAs of $P$. lemoignei LMG $2207^{\mathrm{T}}$ and strains A62 and A52 had $\% \mathrm{G}+\mathrm{C}$ contents of $59.7,58.9$, and $59.5 \mathrm{~mol} \%$, respectively. The DNA-DNA binding ratios were $100 \%$ for strains A62 and A52, 61\% for strain A62 and P. lemoignei LMG $2207^{\mathrm{T}}$, and $60 \%$ for strain A52 and P. lemoignei LMG $2207^{\mathrm{T}}$.

$P$. lemoignei was isolated and described more than 30 years ago and is recognized as one of the first known $\mathrm{P}(3 \mathrm{HB})$-degrading microorganisms (7). Of the three strains isolated originally, only one was preserved. Since then, numerous PHAdegrading microorganisms have been isolated, but none of them had the characteristics of $P$. lemoignei. It was presumed that this species is not representative of the PHA-degrading 
TABLE 2. Overall levels of similarity between the $16 \mathrm{~S}$ rDNA sequences of $P$. lemoignei LMG $2207^{\mathrm{T}}$ and strain A62 and the $16 \mathrm{~S}$ rDNA sequences of 19 representatives of the beta subclass of the Proteobacteria and E. coli

\begin{tabular}{|c|c|c|c|c|}
\hline \multirow[b]{2}{*}{ Species } & \multirow[b]{2}{*}{ Strain } & \multirow{2}{*}{$\begin{array}{c}\text { EMBL } \\
\text { accession } \\
\text { no. }\end{array}$} & \multicolumn{2}{|c|}{$\begin{array}{l}\text { Level of } \\
\text { similarity to: }\end{array}$} \\
\hline & & & $\begin{array}{l}\text { Strain } \\
\text { LMG } \\
2207^{\mathrm{T}}\end{array}$ & $\begin{array}{c}\text { Strain } \\
\text { A62 }\end{array}$ \\
\hline Pseudomonas lemoignei & LMG $2207^{\mathrm{T}}$ & $X 92554$ & 1.00 & 0.99 \\
\hline Pseudomonas lemoignei & A62 & X92555 & 0.99 & 1.00 \\
\hline Zoogloea ramigera & ATCC 25935 & X74914 & 0.94 & 0.94 \\
\hline Zoogloea ramigera & ATCC $19544^{\mathrm{T}}$ & X74913 & 0.90 & 0.89 \\
\hline Burkholderia solanacearum & ATCC $11696^{\mathrm{T}}$ & X67036 & 0.92 & 0.92 \\
\hline Burkholderia cepacia & ATCC $25416^{\mathrm{T}}$ & M22518 & 0.90 & 0.90 \\
\hline Alcaligenes eutrophus & Unknown & M32021 & 0.91 & 0.91 \\
\hline Alcaligenes faecalis & Unknown & M22467 & 0.90 & 0.90 \\
\hline Pseudomonas andropogonis & ATCC 23061 & X67037 & 0.91 & 0.91 \\
\hline Rhodocyclus tenuis & DSM $109^{\mathrm{T}}$ & D16208 & 0.90 & 0.90 \\
\hline Rubrivivax gelatinosus & ATCC $17011^{\mathrm{T}}$ & M34132 & 0.89 & 0.90 \\
\hline Comamonas testosteroni & ATCC $11996^{\mathrm{T}}$ & M11224 & 0.89 & 0.89 \\
\hline Nitrosomonas europaea & Unknown & $\ldots$ & 0.88 & 0.89 \\
\hline Neisseria gonorhoeae & Unknown & M34130 & 0.88 & 0.88 \\
\hline Azoarcus indiges & VB32 & L15531 & 0.88 & 0.88 \\
\hline Methylophilus methylotrophus & ATCC $53528^{\mathrm{T}}$ & L15475 & 0.88 & 0.88 \\
\hline Escherichia coli & Unknown & $-b$ & 0.82 & 0.81 \\
\hline
\end{tabular}

${ }^{a}$ See reference 32.

${ }^{b}$ See reference 6 .

microflora that occurs in the environment (27). By using an enrichment procedure in which $\mathrm{P}(3 \mathrm{HV})$ was the sole source of carbon and energy, we succeeded in isolating from soils 10 strains that are able to degrade $\mathrm{P}(3 \mathrm{HV})$ and $\mathrm{P}(3 \mathrm{HB})$ in vitro and have cultural characteristics very similar to those of $P$. lemoignei $\mathrm{LMG} 2207^{\mathrm{T}}$. Such strains could not be isolated when the enrichment procedure was omitted, and no other $\mathrm{P}(3 \mathrm{HV})$ degrading strains were isolated after enrichment. This indicates that the enrichment procedure in which $\mathrm{P}(3 \mathrm{HV})$ granules are used as the sole source of carbon and energy seems to be especially appropriate for the isolation of $P$. lemoignei strains from soils.

To verify that the new isolates were $P$. lemoignei strains, they were compared with $P$. lemoignei LMG $2207^{\mathrm{T}}$ by performing fatty acid, protein, and plasmid analyses and by using breathprinting. The results clearly showed that the $\mathrm{P}(3 \mathrm{HV})$-degrading strains isolated in this study are phenotypically almost identical to each other and very similar to $P$. lemoignei LMG $2207^{\mathrm{T}}$. The $\mathrm{G}+\mathrm{C}$ contents of the DNAs of strains A52 and A62 are very similar to the value obtained for $P$. lemoignei $\mathrm{LMG}$ $2207^{\mathrm{T}}(59.7 \mathrm{~mol} \%)$ and the value published previously for $P$. lemoignei LMG $2207^{\mathrm{T}}$ by Delafield et al. (7) (58.2 mol\%). A close phylogenetic relationship between the 10 new isolates and $P$. lemoignei was demonstrated by aligning the $16 \mathrm{~S}$ rDNA sequences of representative strain A62 and P. lemoignei LMG $2207^{\mathrm{T}}$; a level of $16 \mathrm{~S}$ rDNA sequence similarity of more than 0.99 was obtained. The levels of hybridization between strain A52 and A62 DNAs and $P$. lemoignei LMG $2207^{\mathrm{T}}$ DNA were 60 and $61 \%$, respectively. Therefore, we identified strains A51, A52, A53, A58, A60a, A60b, A62, A64, K21, and K24 as P. lemoignei strains.

$P$. lemoignei is not an authentic member of the genus Pseudomonas, whose members belong to the gamma subclass of the Proteobacteria (38). It has been shown by rRNA-DNA hybridization that $P$. lemoignei is phylogenetically related to rRNA group III of De Vos and De Ley (10). This group constitutes one of the branches within the beta subclass of the Proteobacteria (38) and includes microorganisms now classified as Burkholderia sp. and $A$. eutrophus. This finding is supported by our phylogenetic data. Strain A62 and P. lemoignei LMG $2207^{\mathrm{T}}$ exhibited more than 0.91 overall similarity in their 16S rDNA sequences to $B$. solanacearum and $A$. eutrophus and 0.94 overall similarity to $Z$. ramigera ATCC 25935. Strain ATCC 25935 (= IAM 12670) is not an authentic Zoogloea strain and is related to Burkholderia cepacia and A. eutrophus (36). However, the taxonomic homogeneity of the genus Burkholderia has been questioned, and the removal of B. solanacearum and Burkholderia pickettii from the genus has been proposed (12, 21). In contrast to Burkholderia species (including $B$. solanacearum and $B$. pickettii) (12) and $A$. eutrophus (18), $P$. lemoignei is able to grow only on a very limited number of substrates. The hydroxylated fatty acid fraction of $P$. lemoignei cells contains 3-hydroxydecanoic acid (10:0 3OH), 3-hydroxydodecanoic acid (12:03OH), and 2-hydroxytetradecanoic acid (14:0 2OH), while Burkholderia cells (including $B$. solanacearum and $B$. pickettii cells) typically contain 3-hydroxytetradecanoic acid $(14: 03 \mathrm{OH})(12,42,44$; this study). $P$. lemoignei may constitute a separate phylogenetic branch within the beta subclass of the Proteobacteria, but its phylogenetic relationships with other members of this branch have to be scrutinized further before any nomenclatural proposal can be formulated.

\section{ACKNOWLEDGMENTS}

Part of this work was supported by European Union ECLAIR grant AGRE.0006.C [H] and AIR2 grant CT93-1099 and by Deutsche Forschungsgemeinschaft grant DFG-152-2-2. D.J. and A.S. thank Wella AG for providing Biopol bottles. K.K. acknowledges the Fonds voor Geneeskundig Wetenschappelijk Onderzoek for personnel and research grants.

We are indebted to M. Hoppert, Institut für Microbiologie der Georg-August-Universität zu Göttingen, for preparing the electron micrographs.

\section{REFERENCES}

1. Alcorn, S. M., T. V. Orum, A. G. Steigerwalt, J. M. Foster, J. C. Fogleman, and D. J. Brenner. 1991. Taxonomy and pathogenicity of Erwinia cacticida sp. nov. Int. J. Syst. Bacteriol. 41:197-212.

2. Anderson, A. J., and E. A. Dawes. 1990. Occurrence, metabolism, metabolic role, and industrial uses of bacterial polyhydroxyalkanoates. Microbiol. Rev. 54: $450-472$.

3. Anderson, A. J., G. W. Haywood, and E. A. Dawes. 1990. The biosynthesis and composition of bacterial polyhydroxyalkanoates. Int. J. Biol. Macromol. 12:102-105.

4. Brandl, H., R. A. Gross, R. W. Lenz, and R. C. Fuller. 1988. Pseudomonas oleovorans as a source of poly( $\beta$-hydroxyalkanoates) for potential applications as biodegradable polyesters. Appl. Environ. Microbiol. 54:1977-1982.

5. Briese, B. H., D. Jendrossek, and H. G. Schlegel. 1994. Degradation of poly(3-hydroxybutyrate-co-3-hydroxyvalerate) by aerobic sewage sludge. FEMS Microbiol. Lett. 117:107-112.

6. Brosius, J., T. J. Dull, D. D. Sleeter, and H. F. Noller. 1981. Gene organization and primary structure of a ribosomal RNA operon from Escherichia coli. J. Mol. Biol. 148:107-127.

7. Delafield, F. P., M. Doudoroff, N. J. Palleroni, J. Lusty, and R. Contopoulos. 1965 . Decomposition of poly- $\beta$-hydroxybutyrate by pseudomonads. J. Bacteriol. 90:1455-1466.

8. De Ley, J. 1970. Reexamination of the association between melting point, buoyant density, and chemical base composition of deoxyribonucleic acid. J. Bacteriol. 101:738-754.

9. De Ley, J., H. Cattoir, and A. Reynaerts. 1970. The quantitative measurement of DNA hybridization from renaturation rates. Eur. J. Biochem. 12: 133 142 .

10. De Vos, P., and J. De Ley. 1983. Intra- and intergeneric similarities of Pseudomonas and Xanthomonas ribosomal ribonucleic acid cistrons. Int. J. Syst. Bacteriol. 33:487-509.

11. Doi, Y. 1990. Microbial polyesters. VCH Publishers, Inc., New York.

12. Gillis, M., V. Tran Van, R. Bardin, M. Goor, P. Hebbar, A. Willems, P. Segers, K. Kersters, T. Heulin, and M. P. Fernandez. 1995. Polyphasic taxonomy in the genus Burkholderia leading to an emended description of 
the genus and proposition of Burkholderia vietnamiensis sp. nov. for $\mathrm{N}_{2}$-fixing isolates from rice in Vietnam. Int. J. Syst. Bacteriol. 45:274-289.

13. Jendrossek, D., A. Frisse, A. Behrends, M. Andermann, H. D. Kratzin, T. Stanislawskj, and H. G. Schlegel. 1995. Biochemical and molecular characterization of the Pseudomonas lemoignei polyhydroxyalkanoate depolymerase system. J. Bacteriol. 177:596-607.

14. Jendrossek, D., I. Knoke, R. H. Habibian, A. Steinbüchel, and H. G. Schlegel. 1993. Degradation of poly(3-hydroxybutyrate), PHB, by bacteria and purification of novel PHB depolymerase of Comamonas sp. J. Environ. Polymer Degrad. 1:53-63.

15. Jukes, T. H., and C. R. Cantor. 1969. Evolution of protein molecules, p. 21-132. In H. N. Munro (ed.), Mammalian protein metabolism. Academic Press, New York.

16. Kado, C. I., and S.-T. Liu. 1981. Rapid procedure for detection and isolation of large and small plasmids. J. Bacteriol. 145:1365-1373.

17. Karlson, U., D. F. Dwyer, S. W. Hooper, E. R. B. Moore, K. N. Timmis, and L. D. Eltis. 1993. Two independently regulated cytochromes P-450 in a Rhodococcus rhodochrous strain that degrades 2-ethoxyphenol and 4-methoxybenzoate. J. Bacteriol. 175:1467-1474.

18. Kersters, K., and J. De Ley. 1984. Genus Alcaligenes Castellani and Chalmers $1919,936^{\text {AL }}$, p. 361-373. In N. R. Krieg and J. G. Holt (ed.), Bergey's manual of systematic bacteriology, vol. 1. Williams and Wilkins, Baltimore.

19. Laemmli, U. K. 1970. Cleavage of structural proteins during the assembly of the head of bacteriophage T4. Nature (London) 227:680-685.

20. Larsen, N., G. J. Olsen, B. L. Maidak, M. J. McCaughey, R. Overbeek, T. J. Macke, T. L. Marsch, and C. R. Woese. 1993. The Ribosomal Database Project. Nucleic Acids Res. 21:3021-3023.

21. Li, X., M. Dorsch, T. Del Dot, L. I. Sly, E. Stackebrandt, and A. C. Hayward. 1993. Phylogenetic studies of the rRNA group II pseudomonads based on 16S rRNA gene sequences. J. Appl. Bacteriol. 74:324-329.

22. Marmur, J. 1961. A procedure for the isolation of deoxyribonucleic acid from microorganisms. J. Mol. Biol. 3:208-218.

23. Marmur, J., and P. Doty. 1962. Determination of the base composition of deoxyribonucleic acid from its thermal denaturation temperature. J. Mol. Biol. 5:109-118.

24. Mergaert, J., C. Anderson, A. Wouters, and J. Swings. 1994. Microbial degradation of poly(3-hydroxybutyrate) and poly(3-hydroxybutyrate-co-3-hydroxyvalerate) in compost. J. Environ. Polymer Degrad. 2:177-183.

25. Mergaert, J., C. Anderson, A. Wouters, J. Swings, and K. Kersters. 1992. Biodegradation of polyhydroxyalkanoates. FEMS Microbiol. Rev. 103:317322.

26. Mergaert, J., L. Verdonck, and K. Kersters. 1993. Transfer of Enwinia ananas (synonym, Erwinia uredovora) and Erwinia stewartii to the genus Pantoea emend. as Pantoea ananas (Serrano 1928) comb. nov. and Pantoea stewartii (Smith 1898) comb. nov., respectively, and description of Pantoea stewartii subsp. indologenes subsp. nov. Int. J. Syst. Bacteriol. 43:162-173.

27. Mergaert, J., A. Webb, C. Anderson, A. Wouters, and J. Swings. 1993. Microbial degradation of poly(3-hydroxybutyrate) and poly(3-hydroxybutyrate-co-3-hydroxyvalerate) in soils. Appl. Environ. Microbiol. 59:32333238.

28. Mergaert, J., A. Wouters, C. Anderson, and J. Swings. 1995. In situ biodegradation of poly(3-hydroxybutyrate) and poly(3-hydroxybutyrate-co-3-hy- droxyvalerate) in natural waters. Can. J. Microbiol. 41(Suppl. 1):154-159.

29. Mergaert, J., A. Wouters, and J. Swings. 1994. Estimation of the intrinsic biodiversity among poly(3-hydroxyalkanoates) degrading streptomycetes using gas chromatographic analysis of fatty acids. Syst. Appl. Microbiol. 17: 601-612.

30. Müller, B., and D. Jendrossek. 1993. Purification and properties of poly(3hydroxyvaleric acid) depolymerase from Pseudomonas lemoignei. Appl. Microbiol. Biotechnol. 38:487-492.

31. Olsen, G. J. 1987. The earliest phylogenetic branchings: comparing rRNAbased evolutionary trees inferred with various techniques. Cold Spring Harbor Symp. Quant. Biol. 52:825-838.

32. Olsen, G. J., N. Larsen, and C. R. Woese. 1991. The Ribosomal RNA Database Project. Nucleic Acids Res. 19:2017-2021.

33. Schirmer, A., D. Jendrossek, and H. G. Schlegel. 1993. Degradation of poly(3-hydroxyoctanoic acid) [P(3HO)] by bacteria: purification and properties of a $\mathrm{P}(3 \mathrm{HO})$ depolymerase from Pseudomonas fluorescens GK13. Appl. Environ. Microbiol. 59:1220-1227.

34. Schirmer, A., C. Matz, and D. Jendrossek. 1995. Substrate specificities of poly(hydroxyalkanoate)-degrading bacteria and active site studies on the extracellular poly(3-hydroxyoctanoic acid) depolymerase of Pseudomonas fluorescens GK13. Can. J. Microbiol. 41(Suppl. 1):170-179.

35. Schlegel, H. G., H. Kaltwasser, and G. Gottschalk. 1961. Ein Submersverfahren zur Kultur wasserstoffoxidierender Bakterien: Wachstumsphysiologische Untersuchungen. Arch. Mikrobiol. 38:209-222.

36. Shin, Y. K., A. Hiraishi, and J. Sugiyama. 1993. Molecular systematics of the genus Zoogloea and emendation of the genus. Int. J. Syst. Bacteriol. 43:826831 .

37. Sneath, P. H. A., and R. R. Sokal. 1973. The principles and practice of numerical classification. Freeman and Co., San Francisco.

38. Stackebrandt, E., R. G. E. Murray, and H. G. Trüper. 1988. Proteobacteria classis nov., a name for the phylogenetic taxon that includes the "purple bacteria and their relatives." Int. J. Syst. Bacteriol. 38:321-325.

39. Steinbüchel, A. 1991. Polyhydroxyalkanoic acids, p. 123-213. In D. Byrom (ed.), Biomaterials. Macmillan Press, London.

40. Steinbüchel, A., E. Debzi, R. H. Marchessault, and A. Timm. 1993. Synthesis and production of poly(3-hydroxyvaleric acid) homopolymer by Chromobacterium violaceum. Appl. Microbiol. Biotechnol. 39:443-449.

41. Steinbüchel, A., and H. E. Valentin. 1995. Diversity of bacterial polyhydroxyalkanoic acids. FEMS Microbiol. Lett. 128:219-228.

42. Urakami, T., C. Itro-Yoshida, H. Araki, T. Kijima, K.-I. Suzuki, and K. Komagata. 1994. Transfer of Pseudomonas plantarii and Pseudomonas glumae to Burkholderia as Burkholderia spp. and description of Burkholderia vandii sp. nov. Int. J. Syst. Bacteriol. 44:235-245.

43. Wilson, K. 1987. Preparation of genomic DNA from bacteria, p. 2.4.1-2.4.2. In F. M. Ausubeland, R. Brent, R. E. Kingston, D. D. Moore, J. G. Seidman, J. A. Smith, and K. Struhl (ed.), Current protocols in molecular biology. John Wiley, New York.

44. Yabuuchi, E., Y. Kosako, H. Oyaizu, I. Yano, H. Hotta, Y. Hashimoto, T. Ezaki, and M. Arakawa. 1992. Proposal of Burkholderia gen. nov. and transfer of seven species of the genus Pseudomonas homology group II to the new genus, with the type species Burkholderia cepacia (Palleroni and Holmes 1981) comb. nov. Microbiol. Immunol. 36:1251-1275. 